\title{
Ecoefficiency of water and wastewater management in food production: A case study from a large dairy in Denmark
}

Skrydstrup, Julie; Larsen, Sille Lyster; Rygaard, Martin

Published in:

Journal of Industrial Ecology

Link to article, DOI:

10.1111/jiec.13011

Publication date:

2020

Document Version

Peer reviewed version

Link back to DTU Orbit

Citation (APA):

Skrydstrup, J., Larsen, S. L., \& Rygaard, M. (2020). Ecoefficiency of water and wastewater management in food production: A case study from a large dairy in Denmark. Journal of Industrial Ecology, 24(5), 1101-1112. https://doi.org/10.1111/jiec.13011

\section{General rights}

Copyright and moral rights for the publications made accessible in the public portal are retained by the authors and/or other copyright owners and it is a condition of accessing publications that users recognise and abide by the legal requirements associated with these rights.

- Users may download and print one copy of any publication from the public portal for the purpose of private study or research.

- You may not further distribute the material or use it for any profit-making activity or commercial gain

- You may freely distribute the URL identifying the publication in the public portal 
1 Eco-efficiency of water and wastewater management

2 in food production using value added and life-cycle

3 assessment

4

5

6

7

8 Keywords: Resource recovery, Wastewater treatment, Industrial water management, Holistic

9 decision-making, Food production, Value chain 
16 Rising water demands and pressures on water resources call for water management in industrial

17 production. An eco-efficiency framework may provide justification for water consumption and

18 treatment, by combining environmental and economic dimensions in a life cycle perspective. We

19 used principles of value added and value chain assessment in the life-cycle system boundaries for

20 a consistent assessment of eco-efficiency. The method was demonstrated for a membrane

21 bioreactor based decentralized wastewater treatment and reuse in a dairy. The LCA results showed

22 that decentralized wastewater treatment and reuse in the dairy will improve the aquatic

23 environment by $80 \%$ (freshwater) and 51\% (marine water), but increase the negative impact on

24 climate change by $27 \%$ compared to conventional wastewater treatment. The value chain

25 assessment revealed that the decentralized alternatives would increase the value added by 1.3 to

$261.4 €$ per $\mathrm{m}^{3}$ wastewater in the dairy, but also incur a value loss of 1.4 to $1.9 € / \mathrm{m}^{3}$ for associated

27 stakeholders such as the centralized wastewater treatment plant. The case study revealed the

28 critical nature of a well-defined system boundary that includes impacts along the entire value chain

29 and exposed pros and cons for decision makers at both the system level and individual stakeholder $30 \quad$ level. 
34 Water scarcity is a growing concern for both developing and developed countries. Growing

35 populations, changes in climate and inefficient use of our water resources are key drivers for

36 developing water management of the future (Stakhiv and Stewart 2010). New technologies are

37 introduced every day aiming to solve water issues; however it is often complex to assess whether

38 they are suitable in life-cycle environmental and economic terms and for all involved actors.

39 Eco-efficiency has been proposed as a holistic approach that considers a system, technology or a

40 product from both an environmental and economic perspective, across the life-cycle and actors

41 (Bidwell and Verfaillie 2000). The eco-efficiency assessment aims to support decisions that will

42 create more economic value while reducing environmental impacts. The method was

43 internationally standardized in 2012 by ISO 14045 (2012). The ISO standard requires use of the

44 Life Cycle Assessment (LCA) framework for the environmental analysis. However, the ISO

45 standard does not require a specific method for value assessment. Life Cycle Costing is a

46 common measure of a systems monetary value (Lorenzo-Toja et al. 2016), but varying

47 approaches are still explored in the literature (Martinez-Sanchez et al. 2015; Heijungs et al. 2013;

48 Faragò et al. 2019).

49 As a closely related alternative to LCC, Value Added (VA) is a metric for economic

50 performance that represents a core mission of businesses, i.e. value creation (Azapagic and

51 Perdan 2000). It has been applied in earlier evaluations of the food industry (Laso et al. 2018;

52 Rivera and Azapagic 2016). In the literature, VA is defined as "the value from sales of all

53 outputs minus the cost of inputs "(Sikdar et al. 2004; Azapagic and Perdan 2000). However, the

54 ambiguity of the VA concept is obvious because the definition of inputs and outputs used in the

55 VA assessment varies across studies. Clift (2009) states that inputs in VA should only cover 
ancillary materials and energy, while Sikdar et. al. (2004) advocates for the inclusion of

57 investments too. On the contrary, Hunkeler et. al. (2008) wants inputs to also cover cost of

58 services purchased (e.g labor), but do not want the sales of co-products (e.g. whey in the

59 production of cheese) to be included in the outputs. VA has the strength of being a parameter

60 businesses can relate to due to its resemblance of gross profit. VA prevents double counting

61 (Moreau and Weidema 2015) and can be consistent with the boundaries of LCA and still include

62 all upstream and downstream costs (e.g, End-of-Life costs) (Hunkeler et al. 2008). To fulfill the

63 boundary of the LCA, VA has to include investments in new technology and anticipated future

64 costs as explained by Martinez-Sanchez et al. (2015)

65 The food industry is the third largest consumer of water worldwide, mainly due to

66 cooling and heating processes and high hygienic standards (Rad and Lewis 2014). In Denmark,

67 the food processing industry accounts for $43 \%$ of the industrial water consumption, and the

68 dairy industry comprises $9.2 \%$ of food processing's water consumption (Naturstyrelsen 2013).

69 Danish Nature Agency (Naturstyrelsen 2013) estimated a potential 20-30\% reduction in the total

70 water demand in dairies by reusing water from cleaning systems and excess milk water

71 compared to a baseline with no on-site water reuse. Besides high drinking water consumptions,

72 dairies are often accountable for a wastewater production exceeding the water consumption due

73 to a $87 \%$ water content in raw milk (Naturstyrelsen 2013). Wastewater from the dairy industry

74 has a higher organic load than domestic wastewater, which, besides the high flow, puts

75 additional pressure on the centralized wastewater treatment plants (WWTP). Industrial

76 wastewater production can be restricted by pollution regulations, but in some areas also by the

77 capacity of the local WWTP. Changes in dairy production may lead to changes in wastewater

78 production volume and composition and therefore, some dairies experience two drivers for 
79 efficient water use: reduced water import and reduced wastewater effluent. An on-site

80 wastewater treatment plant can allow the dairy to increase the production capacity without

81 increasing wastewater production. One example is the use of membrane bioreactors (MBR),

82 achieving a high quality effluent due to the increased removal of organic matter, phosphorus,

83 ammonium, particles, bacteria and viruses compared to conventional wastewater treatment

84 (Deowan et al. 2015). MBR technology has the benefit of being compact and well suited to fit in

85 existing production facilities as a decentralized WWTP. The small area requirement and the high

86 treatment efficiency makes the MBR technology attractive for dairies. In combination with

87 reverse osmosis (RO) MBR treatment of water can achieve drinking water quality and thereby

88 facilitate unrestricted wastewater reuse. Water reclamation within a major food processing

89 industry has broad relevance across the variety of food processing industries (Compton et al.

90 2018; Meneses et al. 2017).

91 Our study aims to develop and demonstrate a method for eco-efficiency assessment

92 consistent with both concepts of value added and life-cycle assessment and use a uniform system

93 boundary for both the economic and environmental assessments. Also, our study provides an

94 example of the eco-efficiency potential of a decentralized wastewater reuse facility. The example

95 is based on actual data from the dairy factory HOCO, located in Denmark and the anticipated

96 implementation of a Grundfos Biobooster for local wastewater treatment and water recovery.

98 METHOD

99 Our eco-efficiency assessment was based on a five step methodology aligned with ISO (2012):

100 1) Goal and Scope definition, 2a) Life-cycle assessment, 2b) Value chain assessment, 3)

101 Quantification of eco-efficiency, and 4) Interpretation with sensitivity and uncertainty analysis. It 
102 was the aim to have a direct link between the LCA and value chain assessment (VCA) that

103 ensures consistent system boundaries for both assessments.

Goal and Scope definition. The goal was to evaluate the eco-efficiency of alternative

105 ways of handling HOCO's wastewater and compare these to today's business-as-usual approach.

106 In 2015, HOCO produced 17,000 tonnes of milk powder using 544,099 m3 of drinking water and

107530,000 tonnes of raw milk (Nielsen 2016). The life cycle covered HOCO's water chain, defined

108 as water related processes required for $\mathrm{HOCO}$ to produce milk powder and by-products. A

109 consequential life cycle inventory (LCI) formed basis for both the environmental and economic

110 assessment. Therefore, the system boundary only included processes affected by changes made

111 to the original system. The system was simplified by only including processes that were expected

112 to be affected more than $1 \%$ per unit cost, mass or energy flow per year. Both foreground and

113 background impacts (See S1) were included in the system. The functional unit (FU) was

114 "treatment of $1000 \mathrm{~m}^{3} \mathrm{HOCO}$ wastewater", and the analysis assumed a 20 years operation of the

115 treatment plant, assuming constant wastewater composition based on 2015 (Table 1). Reclaimed

116 water needed to fulfill the regulations of 2015 as stated by Ministry of Environment and Food of

117 Denmark (Table 1) for both wastewater effluent (Miljø- og Fødevareministeriet 2016a) and

118 drinking water (Miljø- og Fødevareministeriet 2015). 2015 was the reference year of the system

119 (Bhupendra 2016).

120 Table 1. HOCO's wastewater characteristics in 2015 as well as a selection of relevant Danish

121 water quality parameters for wastewater effluent and drinking water.

\begin{tabular}{lcccc}
\hline Parameter & HOCO & $\begin{array}{c}\text { Wastewater } \\
\text { effluent criteria }\end{array}$ & $\begin{array}{c}\text { Drinking } \\
\text { water criteria }\end{array}$ & Unit \\
\hline Volume & 624,735 & - & - & $\mathrm{m}^{3}$
\end{tabular}




\begin{tabular}{lcccr}
\hline COD & 1500 & $<75$ & - & $\mathrm{mg} / 1$ \\
Total nitrogen (T-N) & 118 & $<8$ & - & $\mathrm{mg} / 1$ \\
Total phosphorus (T-P) & 30 & $<1.5$ & $<0.15$ & $\mathrm{mg} / 1$ \\
Temperature & 30 & - & $<12$ & ${ }^{\circ} \mathrm{C}$ \\
$\mathrm{pH}$ & 9 & - & $7-8.5$ & - \\
\hline
\end{tabular}

Case description. A Baseline case represented the current wastewater management at

124 HOCO. In the Baseline, Nibsbjerg waterworks in Holstebro provided drinking water to HOCO

125 and the centralized Holstebro wastewater treatment plant (WWTP) treated wastewater before

126 discharge to the river Storå. Wastewater sludge was sent to Maabjerg Energy Center (MEC), a

127 biogas plant that produces electricity and heat. Stabilized sludge from MEC substituted fertilizer

128 on the fields in local farm areas (Figure 1). Two decentralized alternatives were considered. The

129 first alternative A1 MBR-nature would treat the wastewater at $\mathrm{HOCO}$ to the same effluent

130 standards as in the Baseline and discharge it to the same river. Sludge would be send by truck

131 from HOCO to MEC. In the second alternative $A 2 M B R$-reuse, the MBR was amended by a RO

132 plant and chlorine disinfection to produce reclaimed potable water. The reclaimed water would

133 have drinking water quality and substitute drinking water import from Nibsbjerg waterworks to

134 the dairy. The RO concentrate would be pumped to Holstebro WWTP for treatment. Similar to

135 the other alternatives, sludge would be treated at MEC and stabilized sludge used as fertilizer

136 (Figure 1). 

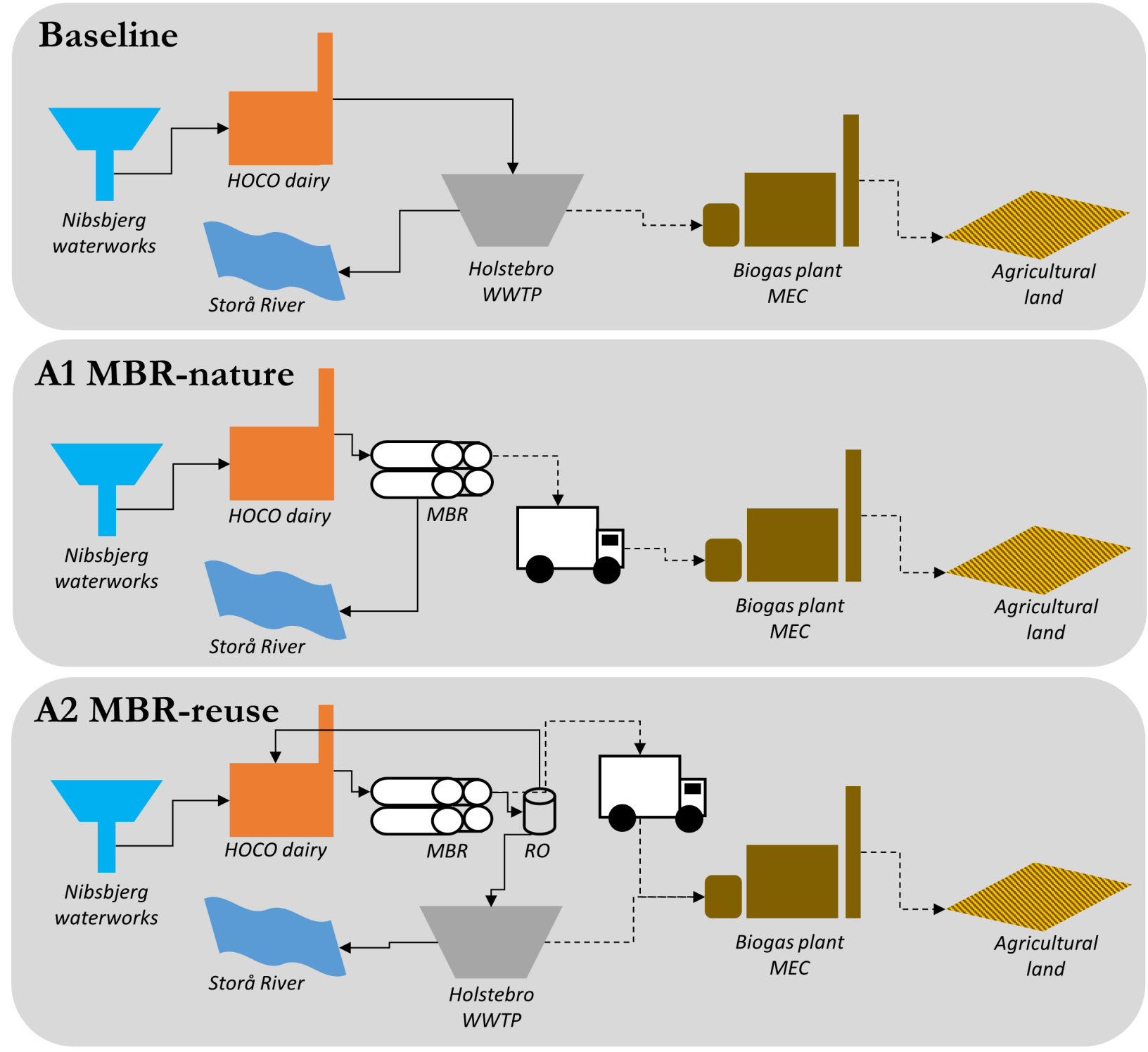

139 Figure 1. The conceptual water chain for the baseline and alternatives evaluated in the eco-

140 efficiency assessment. Solid lines indicate flow of water, and dotted lines indicate flow of sludge.

141 WWTP: Wastewater Treatment Plant, MEC; Maabjerg Energy Center, MBR: Membrane

142 Bioreactor, RO: Reverse Osmosis.

Life-Cycle Assessment. The environmental impacts were modeled using EASETECH

144 (Technical University of Denmark 2016) (Version 2), which is based on mass flow analysis and 
145 keeps control of homogeneous and heterogeneous flows (Clavreul et al. 2014). The main 146 stakeholders related to the water system were Nibsbjerg waterworks, Holsterbro WWTP, MEC, 147 and the farmers in the area who would receive the stabilized sludge from MEC.

148 Inventory. E-mail and telephone correspondences with contact persons from the different 149 stakeholders provided the majority of the foreground data. Data were process data from 2015, 150 whenever it was available. If not available, data were estimated based on literature and stakeholder 151 employees. The design of the MBR was provided by Grundfos and based on HOCO's data from 152 2015. Background data, e.g for production of chemicals, were collected from Ecoinvent (Version 153 3.3) (Frischknecht et al. 2005) (See S1 for general background processes and S2 for data and 154 assumptions for MBR and RO technology).

155 A mass balance for Holstebro WWTP formed basis for our substance flow analysis

156 (Table 2). For example, the total amount of water, COD, T-N and T-P discharged to the river

157 from Holstebro WWTP in 2015 was scaled to HOCO's relative contribution to the total inflow in

158 2015. The same was done for the distribution in the wastewater sludge, except that COD was

159 estimated from the total solids (TS) in the sludge as in Henze et. al. (1999). The mass balances

160 including carbon and nitrogen flows for the MBR were established by design engineers

161 (Bhupendra 2016), and the assumptions and approach used to estimate COD from TS from

162 Holstebro WWTP were repeated for the MBR alternatives. Methane release from wastewater

163 treatment was estimated as suggested by the IPCC guideline (Doorn et al. 2006). Furthermore,

164 it was assumed that T-N in stabilized sludge substitute $45 \%$ of average T-N fertilizer, and that

165 T-P in sludge substitute $100 \%$ of T-P fertilizer, which reflects that the uptake of T-N is not as

166 efficient as T-P (Miljø- og Fødevareministeriet 2016b).

167 Table 2. Water and mass flows to Holstebro WWTP and contributions from HOCO in 2015. 


\begin{tabular}{|lcc|c|}
\hline Parameter & $\begin{array}{c}\text { Total } \\
\text { inflow }\end{array}$ & From HOCO & HOCO Contribution [\%] \\
\hline Flow $\left(1000 \mathrm{~m}^{3} / \mathrm{yr}\right)$ & 5,882 & 625 & 11 \\
COD $(1000 \mathrm{~kg} / \mathrm{yr})$ & 4,782 & 937 & 20 \\
T-N $(1000 \mathrm{~kg} / \mathrm{yr})$ & 337 & 74 & 22 \\
T-P $(1000 \mathrm{~kg} / \mathrm{yr})$ & 67 & 26 & 39 \\
\hline
\end{tabular}

168

172 Withdrawal Impact (FWI) was estimated as suggested by Godskesen et al. (2013) and Hybel et

173 al. (2015). Because all water comes from within the same small region, we chose FWI over the 174 recommended AWARE method (Boulay et al. 2018). Our approach for calculating FWI was

175 developed specifically for groundwater based water supply and based on best available data at the 176 time of the assessment, and at a finer scale than available in the AWARE dataset. The FWI was 177 calculated as:

$$
F W I=Q_{g} \cdot \frac{W U}{W R-E W R}
$$

178 where $\mathrm{Q}_{\mathrm{g}}$ is the water use along the value chain, WU is the total water use, WR is the total water

179 resource and EWR is the environmental water requirements, all given in $\left[\mathrm{m}^{3} / \mathrm{yr}\right]$. WU, WR and

180 EWR were found for the groundwater resource in Nissum Bay catchment, covering the case

181 study area (Miljøministeriet 2011). Water use, $Q_{g}$, is calculated as groundwater abstracted for

182 water supply minus the water returned to the catchment from the WWTP. All water used is

183 sourced within Nissum Bay catchment. 
185 from Laurent et. al. (2013). The normalization factor for FWI was also estimated for an average

186 European person using the method suggested by Godskesen et. al. (2013).

Value Chain Assessment. VA across the entire value chain was considered, and so the VA assessment is referred to as VCA (Macfadyen et al. 2012). The VCA consisted of the

189 same steps as the LCA. The VA for one process $\mathrm{k}$ in the value chain was found as:

$$
\mathrm{VA}=\sum_{\mathrm{k}} \mathrm{UP}_{\mathrm{k}} \cdot \mathrm{Q}_{\mathrm{k}}-\left[\sum_{\mathrm{j}}\left(\mathrm{UP}_{\mathrm{j}} \cdot \mathrm{Q}_{\mathrm{j}}\right)+\sum_{\mathrm{q}} \mathrm{FC}_{\mathrm{q}}\right]
$$

190 where the revenues $[€ / \mathrm{yr}]$ and costs $[€ / \mathrm{yr}]$ were calculated as the unit price of product $(\mathrm{k})(\mathrm{UP}) \times$ 191 supply/demand of product (Q)(Kleinfeld 1993). Costs(j) covered variable costs i.e. costs that vary 192 with production such as electricity, and transfers, e.g., emission taxes and fees on wastewater 193 discharge permission. The costs did not include labor and equity and that left VA as a measure of 194 profit to pay such expenses (Sikdar et al. 2004). In other words, salary counted positively towards 195 the economic value of the system. The future cash flows (FC) [€/yr] included investments $(\mathrm{q})$ that 196 were also relevant for the LCA, which in our case was the investment in new technology. FC was 197 calculated by (Kleinfeld 1993):

$$
F C=P I\left[\frac{i(1+i)^{n}}{(1+i)^{n}-1}\right]-S V\left[\frac{i}{(1+i)^{n}-1}\right]
$$

The present investment (PI) and the salvage value (SV) was given as one-time costs [€], 199 with PI as the current investment price of the technology and SV as the value of the technology 200 at the end of its lifetime. The annual costs are based on assumed lifetimes $\mathrm{n}$ [years] and annual 201 interest $\mathrm{i}(\%)$. The interest rate was assumed to be 3\% (Bankrate 2016) and it was assumed that 202 the salvage value would be $10 \%$ of the initial investment. All costs are reported for year 2016. 
203 We defined the Total Value Added (TVA) as the sum of VAs for each process and summarized

204 for each actor along the value chain.

205 VA was calculated for all processes included in the LCA based on the mass flows. Air

206 emissions were not associated with any expenses and as such the only mass flows not associated

207 with a cost to the stakeholders. Inherent to the consequential approach, only costs and revenues

208 that change between the cases were included. It was assumed that costs and revenues were not

209 affected by external policy choices e.g. a new tax system.

210 Inventory. MBR investment costs and chemical costs were based on observed costs from

211 a similar Swedish dairy factory and provided by Grundfos (Bhupendra 2016). Silhorko

212 (Dalsgaard 2016) provided the investment costs of the RO unit as well as a cleaning and

213 maintenance schedule, however costs of cleaning and treatment chemicals were estimated by an

214 expert (Bhupendra 2016). Costs of electricity, drinking water, wastewater treatment and heat

215 were all provided by the utility Vestforsyningen A/S ( 2015). These unit prices were also used to

216 calculate the respective revenues e.g. for the waterworks.

217 HOCO does not have an actual income related to their sales of products. Instead they

218 receive a yearly amount of money from the mother company Arla corresponding to their

219 expenditures. It was assumed that the dairy production will remain the same for Baseline and

220 both alternative cases. Hence, VA was only reflecting the difference between costs for each case.

221 The VCA included costs of fertilizer. The content of T-N in the sludge was the limiting

222 factor for fertilizer substitution and the changes in costs between cases were calculated based on

223 the T-N content. Baseline had the highest content of T-N in the sludge and could cover the

224 largest area with fertilizer. The optimal amount of T-N on a field depends on the soil and crop

225 type. We used a value of $150 \mathrm{~kg} \mathrm{~N} / \mathrm{ha}$ based on the assumption that the crop is wheat and that 
226 sludge has the same fertilizer value as manure from animals (SEGES 2015). Costs and

227 environmental impacts of producing and using conventional fertilizer negatively impacted the

228 alternative systems per hectare not covered with fertilizer compared to the Baseline. The cost of

229 conventional fertilizer was calculated as $80 € /$ ha (PlanteavlsKonsulenten, No date).

230 Quantification of Eco-efficiency. The eco-efficiency indicator (EEI) combines the

231 environmental and economic dimensions into a single number:

$$
\mathrm{EEI}_{\mathrm{j}, \mathrm{k}}=\mathrm{TVA}_{\mathrm{j}} \cdot \text { Reduced Impact }_{\mathrm{j}, \mathrm{k}}
$$

232 An EEI score was calculated for each impact category (k) for each scenario (j). Only

233 processes that changed were included in the analysis, meaning that EEI should be kept a relative

234 term(Saling et al. 2002; Huppes and Ishikawa 2007; ISO 2012) compared to the Baseline. An

235 increased EEI score will indicate an improved eco-efficiency performance.

236 Sensitivity and uncertainty. A contribution analysis, a perturbation analysis and

237 finally an uncertainty propagation analysis assessed the sensitivity of results to inventory

238 parameters and assessed the overall uncertainty. The method consisted of the following steps

239 (Clavreul et al., 2012):

240 1. Contribution analysis to find the parameters that contributed with more than $5 \%$ to the total 241 results (S7).

242 2. Perturbation analysis to identity sensitive parameters from the contribution analysis.

243 Parameters were changed by $10 \%$.

244 3. Uncertainty propagation to quantify overall uncertainty of results based on $1 / 3$ of the most 245 sensitive and uncertain parameters (S7). Probability theory and Monte Carlo sampling were 246 applied. Parameters were assumed to have a normal distribution with a standard deviation 
estimated from the assessment of the data quality matrix defined by Weidema and Wesnaes (

1996) (S4). 10,000 Monte Carlo iterations were performed.

\section{RESULTS AND DISCUSSION}

250 The largest difference between the Baseline and the alternatives were found for climate change,

251 freshwater eutrophication, marine eutrophication and the freshwater withdrawal impact (S3,

252 Figure S3-S2 and Figure S3-S3). These environmental impacts depend largely on changes in

253 water abstraction for water supply and energy requirements for the MBR treatment of

254 wastewater at the dairy (Table 3).

255 Table 3: A selection of the most influential parameters for the LCA and VCA inventories per

$2561000 \mathrm{~m}^{3}$ of HOCOs wastewater. The unit prices for electricity, drinking water and wastewater

257 are $0.2 € / \mathrm{kWh}, 0.7 € / \mathrm{m}^{3}$ and $2.2 € / \mathrm{m}^{3}$ respectively. For the full inventory see Table S5.

\begin{tabular}{|c|c|c|c|c|}
\hline \multirow[b]{2}{*}{ Parameters } & \multicolumn{3}{|c|}{ Amount } & \multirow[b]{2}{*}{ Comments } \\
\hline & Baseline & A1 & A2 & \\
\hline \multicolumn{5}{|l|}{ Nibsbjerg waterworks } \\
\hline $\begin{array}{l}\text { Groundwater abstraction } \\
{\left[\mathrm{m}^{3}\right]}\end{array}$ & 937 & 937 & 132 & $\begin{array}{l}\text { Groundwater extracted from nearby wellfields. The } \\
\text { volume was calculated by adding } 7.1 \% \text { water loss to } \\
\text { HOCO's drinking water demand in } 2015 \text {. }\end{array}$ \\
\hline $\begin{array}{l}\text { Electricity consumption } \\
{[\mathrm{kWh}]}\end{array}$ & 249 & 249 & 35 & $\begin{array}{l}\text { Scaled to volume purchased by HOCO in } 2015 \text {. } \\
\text { Assumed linear relation between energy consumption } \\
\text { and water flow. Cost of electricity is based on } \\
\text { (Vestforsyningen A/S 2015). }\end{array}$ \\
\hline \multicolumn{5}{|l|}{ HOCO dairy } \\
\hline $\begin{array}{l}\text { Drinking water } \\
\text { consumption }\left[\mathrm{m}^{3}\right]\end{array}$ & 871 & 871 & 123 & $\begin{array}{l}\text { Volume was based on HOCO's total drinking water } \\
\text { demand in } 2015 \text { for Baseline and A1 MBR-nature. The } \\
\text { amount in A2 MBR-reuse was calculated as total } \\
\text { demand minus reclaimed wastewater. }\end{array}$ \\
\hline
\end{tabular}




\begin{tabular}{|l|r|r|r|l|}
\hline $\begin{array}{l}\text { Wastewater to Holstebro } \\
{\left[\mathrm{m}^{3}\right]}\end{array}$ & 1,000 & - & 249 & $\begin{array}{l}\text { Volume was based on HOCO's total wastewater } \\
\text { production in 2015 for Baseline. Volume for A2 MBR- } \\
\text { reuse was RO concentrate. No wastewater production } \\
\text { in A1 MBR-nature. }\end{array}$ \\
\hline $\begin{array}{l}\text { Electricity consumption } \\
{[\mathrm{kWh}]}\end{array}$ & - & 1,705 & 2,277 & $\begin{array}{l}\text { For wastewater treatment only. Based on a MBR design } \\
\text { specifically for HOCO. }\end{array}$ \\
\hline $\begin{array}{l}\text { Methane emission to air } \\
{[\mathrm{kg}]}\end{array}$ & - & 83 & 83 & $\begin{array}{l}\text { For wastewater treatment only. Expected emissions } \\
\text { according to IPCC 2006 guidelines. }\end{array}$ \\
\hline Holstebro WWTP & 1,064 & - & 72 & $\begin{array}{l}\text { The electricity consumption and associated costs were } \\
\text { scaled to HOCO's contribution to the total COD and T- } \\
\text { No Holstebro WWTP in 2015, which was 20\%. }\end{array}$ \\
\hline $\begin{array}{l}\text { Electricity consumption } \\
{[\mathrm{kWh}]}\end{array}$ & 75 & - & 2 & $\begin{array}{l}\text { Expected emissions according to IPCC 2006 } \\
\text { guidelines. }\end{array}$ \\
\hline $\begin{array}{l}\text { Methane emission to air } \\
{[\mathrm{kg}]}\end{array}$ & & &
\end{tabular}



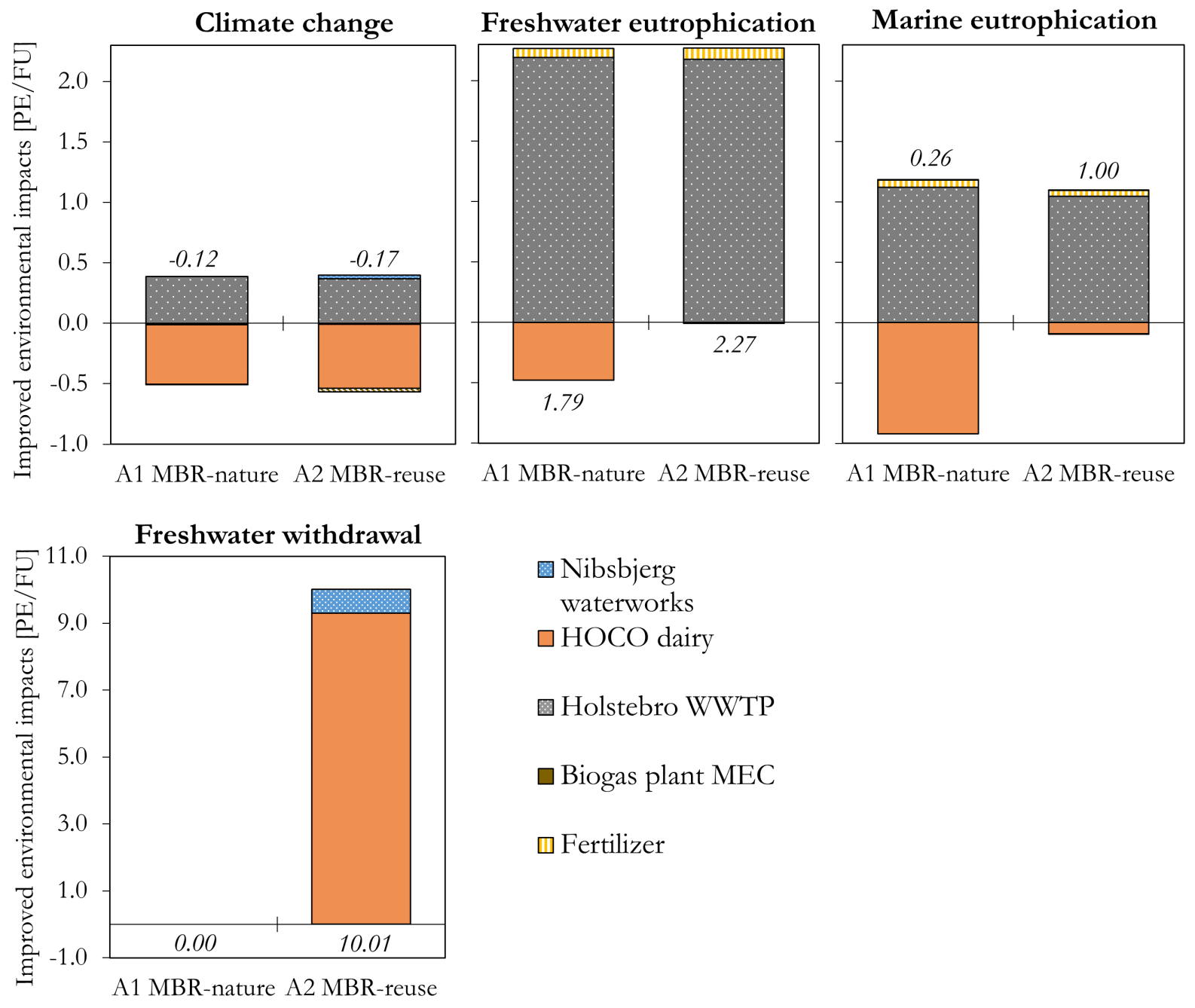

\section{圆 Nibsbjerg waterworks \\ $\square$ HOCO dairy}

圆 Holstebro WWTP

Biogas plant MEC

$\square$ Fertilizer

Figure 2. Normalized LCA results with estimated change in environmental impacts for the two considered alternatives compared to Baseline. A positive change indicates a reduction in environmental impacts, and thus an improvement compared to Baseline. Alternative 1, where treated wastewater is pumped to the recipient (A1 MBR-Nature) generally performs worse than Alternative 2, where wastewater is recycled at

The wastewater treatment efficiency of the MBR technology resulted in a better aquatic

261 environment when considering freshwater and marine eutrophication (Figure 2). In A1 MBR-

262 nature and A2 MBR-reuse, freshwater eutrophication impacts were reduced by $1.8 \mathrm{PE}$ and 2.3

263 PE per $1000 \mathrm{~m}^{3}$. A2 MBR-reuse has the largest environmental savings compared to Baseline 
264 because of improved treatment of wastewater from HOCO. In A2 MBR-reuse water passes the

265 MBR and RO unit and RO concentrate is pumped to the Holsterbro WWTP. A2 MBR-reuse

266 released approximately $97 \%$ less phosphorous to the aquatic environment than A1 MBR-nature

267 and approximately $99 \%$ less than Baseline. Due to the extra treatment in A2 MBR-reuse,

268 marine eutrophication would also decrease with less nitrogen ending up in the ocean. HOCO

269 contributes indirectly to marine eutrophication through the release of $\mathrm{N}_{2} \mathrm{O}$ to air caused by the

$27027 \%$ increase in electricity use for the MBR and RO unit (Figure 10 S6). The RO unit in A2

271 MBR-reuse would produce 467,443 $\mathrm{m}^{3}$ of drinking water from HOCO's wastewater. This

272 amount can substitute $86 \%$ of HOCO's yearly drinking water consumption and reduce the

273 freshwater withdrawal impact by $9.3 \mathrm{PE}$ per $1000 \mathrm{~m}^{3}$ wastewater. As such, freshwater

274 withdrawal represented the highest saving of all considered impact categories. The reclaimed

275 wastewater means less abstracted groundwater at Nibsbjerg waterworks resulting in a total

276 saving of $443 \mathrm{PE}$ compared to Baseline and A1 MBR-nature.

277 These savings for the aquatic environment came at the cost of increased climate change

278 impacts (Figure 2). The increased impact on climate change stemmed primarily from a 60 to 114

$279 \%$ higher electricity consumption by the MBR and MBR plus RO alternatives compared to

280 conventional wastewater treatment (Table 3). Furthermore, there was estimated a $12 \%$ higher

281 methane release from the MBR (Table 3) due to an improved conversion of organic matter.

282 Considering the generally hard water groundwater in Denmark, water softening is necessary to

283 improve overall life expectancy of production equipment. A2 MBR-reuse was found to avoid

284 some electricity use for water softening compared to Baseline. It also reduced the need for gas

285 heating by $29 \%$ due to demineralization by RO and higher temperatures of the reclaimed

286 wastewater (Table S5). Still, such savings were not enough to offset the impacts from increased 
287 energy use in the A2 MBR-reuse compared to Baseline and A1 MBR-nature. The electricity and 288 chemical consumption of Holstebro WWTP dropped for the alternatives A1 MBR-nature and A2

289 MBR-reuse, because less water would be treated at the plant when HOCO treats their own

290 wastewater. Since less drinking water would be produced at Nibsbjerg waterworks in A2 MBR-

291 reuse, Nibsbjerg waterworks would also reduce its electricity consumption compared to

292 Baseline. Again, the savings in impacts from Holstebro WWTP and Nibsbjerg waterworks were 293 not found to off-set the performance of the MBR alternatives.

294 Table 4: The change in VA compared to Baseline given in $€$ /functional unit i.e. $1000 \mathrm{~m}^{3}$ of 295 HOCO's wastewater.

\begin{tabular}{|lccccc|c|}
\hline & $\begin{array}{c}\text { Nibsbjerg } \\
\text { waterworks }\end{array}$ & $\begin{array}{c}\text { HOCO } \\
\text { dairy }\end{array}$ & $\begin{array}{c}\text { Holstebro } \\
\text { WWTP }\end{array}$ & $\begin{array}{c}\text { Biogas plant } \\
\text { MEC }\end{array}$ & Agriculture & TVA \\
\hline A1 MBR-nature & 0 & 1,386 & $-1,918$ & 2 & -6 & -536 \\
A2 MBR-reuse & -454 & 1,307 & $-1,386$ & 0 & -4 & -538 \\
\hline
\end{tabular}

298 performance decreases with a MBR implemented. The VCA, however, showed that HOCO's VA

299 increases with approximately $40 \%$ with the MBR and MBR plus RO implemented (Table 4).

300 Costs associated with discharging wastewater to Holstebro WWTP was found to be around 4

301 times higher than costs related to the MBR. Contrary to the positive impact on HOCO's VA, VA

302 for all other stakeholders was found negative. In A1 MBR-nature, Holsterbro WWTP VA

303 dropped by $1,918 € / 1000 \mathrm{~m}^{3}$. This loss corresponded to $11 \%$ (Table 2 ) of the WWTP's yearly

304 revenue, assuming the only revenue is wastewater treatment. The loss in revenue was less in A2

305 MBR-reuse because the RO concentrate contributes additionally $155,814 \mathrm{~m}^{3}$ wastewater to 
307 compared to Baseline due to an $86 \%$ reduction in water consumption at HOCO. In a broader

308 systems perspective, the overall TVA would not favor the implementation of MBR at HOCO.

309 Compared to the Baseline we estimated a total loss of 536 and $538 € \mathrm{VA}$ per $1000 \mathrm{~m}^{3}$ for the two

310 MBR alternatives.

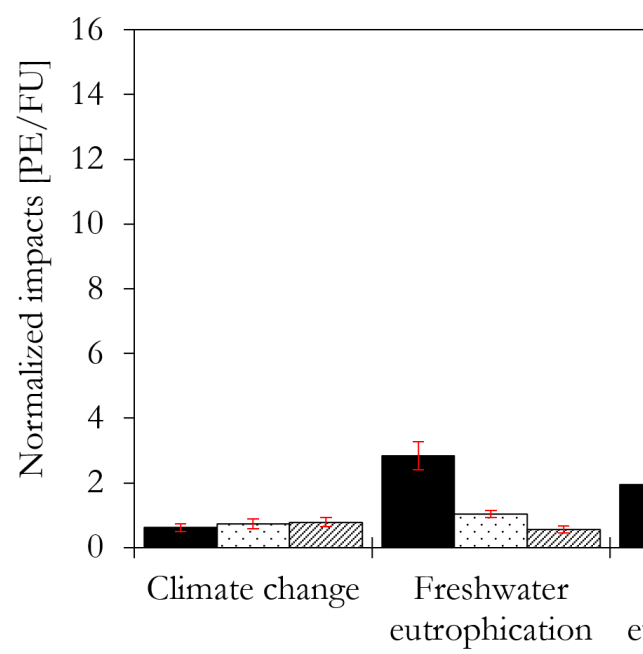

311

312

313

314

315

316

317 eutrophication impacts between all cases (Figure 3). Baseline and A1 MBR-nature had less 318 significant difference for marine eutrophication than Baseline and A2 MBR-reuse. For the 319 economic evaluation, the difference between the two MBR alternatives was not significant. Also,

Figure 3. The uncertainty propagation for the total results of the LCA and VCA estimated from 10,000 Monte Carlo iterations (used parameters and estimated SD in Table 12 S6). FU = Functional unit i.e. $1000 \mathrm{~m}^{3}$ of HOCO's wastewater.

The uncertainty propagation did not support a significant difference between Baseline and the alternatives for the climate change impact. The difference was significant for the freshwater 
320 the uncertainty overlap between Baseline and A1 MBR-nature indicated that Baseline's TVA 321 could potentially be as low as the MBR alternatives.

322 Overall, there are both benefits and drawbacks to the implementation of the MBR alternatives

323 at HOCO. The LCA showed that the savings in quality and quantity of the aquatic environment

324 were on behalf of increased climate change impacts. Similarly, the VCA suggests that the MBR

325 implementation will be economically beneficial for $\mathrm{HOCO}$, while a loss is expected for the entire 326 value chain.

327 Eco-efficiency quantification. Assuming equal weights between environmental impact 328 categories and value added, an eco-efficiency indicator shows that the economic losses were 329 outweighed by the environmental benefits for freshwater withdrawal (A2 MBR-reuse), freshwater 330 and marine eutrophication (Figure 4). This can be perceived an eco-efficiency improvement of the 331 system compared to Baseline, for these impact categories only. On the other hand, if considering 332 climate change and freshwater eutrophication (A1 MBR-nature) alone, the MBR worsens the eco333 efficiency of the system compared to Baseline. A decision will therefore depend markedly on 334 weights assigned by the decision maker to the environmental and economic impacts. Such a 335 weighting scheme is considered outside the focus of our study, but suggestions are found in the 336 literature, e.g. by letting a selection of stakeholders representing different preferences assign 337 weights to the impacts (Søndergaard et al. 2018; Godskesen et al. 2018). 

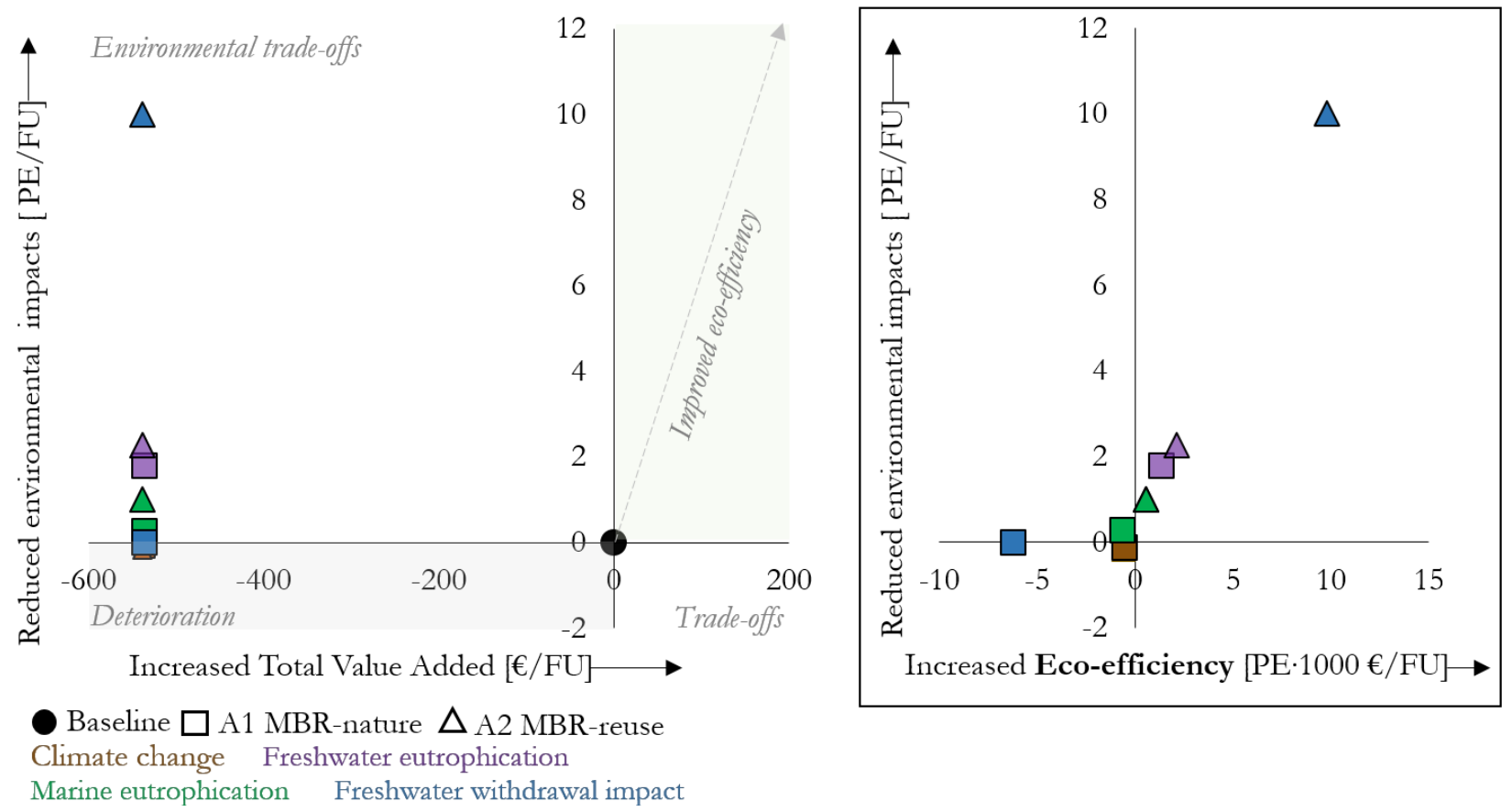

Figure 4. Eco-efficiency quantification of the four considered environmental impact categories and the total value added. Results are relative to Baseline placed in Origo.

Further studies should address the following six shortcomings of our case study: 1) By

344 decentralizing the treatment of HOCO's wastewater, HOCO will be given an opportunity to

345 increase their production, which adds value to HOCO. The potential realization of an increased 346 production is unknown and therefore not included here, but it would benefit the choice of a

347 decentralized MBR treatment plant. 2) With a decentralized wastewater treatment at HOCO,

348 Holstebro WWTP may experience a loss in efficiency, because HOCO's warm wastewater

349 increases the metabolism in the biological tanks (Agerbo 2016). The actual response of the WWTP

350 to a changed inflow composition has not been modelled here, but it would probably punish the

351 environmental performance of the decentralized treatment at HOCO. 3) The MBR technology is

352 better at retaining microorganisms, such as antibiotics, pathogens and micro contaminants

353 compared to conventional treatment. This is an environmental benefit not yet quantified by the 
354 conventional LCA framework (JRC - European commission 2011) but with potential to be 355 included in the future (Harder et al. 2017). 4) Vestforsyningen A/S are planning to build a new 356 WWTP in 2022 as a consequence of the current WWTP reaching its end-of-life (Holstebro 357 municipality 2008). $73 \%$ of the incoming wastewater is from dairies and slaughterhouses (Agerbo 358 2016). If the trend for decentralized wastewater treatment increases, it needs to be included in the 359 dimensioning of the new WWTP and this could lead to considerable savings in the re-investment 360 for Vestforsyningen A/S. 5) It was not the goal and scope of this study to assess how and when

361 VA is spent by stakeholders. The VA assessment provides a one-year snapshot of value generated

362 for each actor. The change in water system operation was assumed to not directly affect prices of 363 e.g. chemicals, change in interest rates, or affect dairy production and disposals. A verification of 364 this assumption would require a second iteration of the VA based on a survey among stakeholders 365 evaluating their responses to the proposed new water system. Their response could lead to new 366 scenarios to be analyzed. 6) The method applied here was designed to quantify relative eco367 efficiency. If the implementation of a water efficient solution leads to an overall increase in 368 production, this might lead to an increase in drinking water demand, wastewater production and 369 energy consumption. This would counteract the benefits and could lead to even higher emissions, 370 the so called rebound effect (Hauschild 2015).

371 These six issues are likely to support the results we found, i.e. that the MBR has positive 372 effects on HOCO's economy and the aquatic environment, but negative effects on the economy of 373 dependent upstream and downstream stakeholders, except for the potential savings at the re374 investment in central wastewater treatment. One important limitation to our study is the lack of 375 measurements of direct GHG emissions from both conventional and MBR wastewater treatment.

376 Future studies should investigate the changes in $\mathrm{CH}_{4}$ and $\mathrm{N}_{2} \mathrm{O}$ emissions related to the biogas 
377 production and nitrogen removal processes. This eco-efficiency assessment documented the 378 economical connection between water supply chain stakeholders, such as Holstebro WWTP and 379 Nibsbjerg waterworks, with their large consumers (e.g. dairies), and how changes can affect them 380 negatively. Considering the high wastewater costs, HOCO would either choose A1 MBR-nature 381 or A2 MBR-reuse. Installing the MBR at $\mathrm{HOCO}$ would result in a net increase in their electricity 382 consumption by $2.6 \%$ for A1 MBR-nature and $3.6 \%$ for A2 MBR-reuse. The increase in 383 electricity for both alternatives does not have a major impact on the costs and environmental 384 impacts already associated with HOCO's electricity consumption. The systematic value chain 385 analysis embedded in our eco-efficiency method has revealed pros and cons important for the 386 decision makers at both the system (authority) level and for the dairy company. On this

387 background, it appears as a valuable framework for any future holistic assessments of water saving 388 initiatives in the food processing industry.

Method evaluation. The method showed how a change for one stakeholder affected other

390 stakeholders within the defined system boundary. This was observed for both environmental

391 impacts and value added and is an important asset of the methodology with more focus on 392 sustainability planning in a more holistic manner. Our method avoided appraisal of environmental 393 impacts in economic terms, e.g. T-P discharge to nature, like in Cost-benefit analysis (Pearce et 394 al. 2006). Monetizing such externalities would introduce more uncertainty to the analysis. Still, 395 VA is a good indicator of the immediate effect on the economic activity. Different from similar 396 studies (Laso et al. 2018; Rivera and Azapagic 2016), we chose to include the value of salaries in 397 the value added as an acknowledgement of the increased economic activity for the stakeholders. 398 These considerations, as well as the fact that the method can be based on the same mass flow 
399 analysis and system boundaries set by an internationally accepted LCA method, makes the applied

400 eco-efficiency method useful and transparent for decision making.

401 As demonstrated above, the eco-efficiency framework developed is useful for 402 accommodating an increasing requirement from society for industries to report on topics like 403 environment, climate and societal costs. The framework further helps identifying links and 404 possible feedback responses of proposed changes to the water management, which will benefit 405 decision makers.

406

407 ASSOCIATED CONTENT

408 Supporting Information

409 List of background processes used in the LCA

410 Construction materials for MBR, RO and recycle potentials,

411 Impact categories and overall results of the LCA performed in EASETECH

412 Data Quality Matrix for LCA and VCA parameters

413 Full inventory for the LCA and VCA

414 Mass balances for COD, T-N and T-P for relevant processes and MC parameters

416 AUTHOR INFORMATION

417 Corresponding Author

418 *Phone (+45) 45251462; email: jusk@env.dtu.dk 


\section{Notes}

420 The authors declare no competing financial interest.

\section{ACKNOWLEDGMENT}

422 We thank Bhupendra Poudel and Søren Nøhr Bak from Grundfos for their expertise on the

423 Grundfos Biobooster and wastewater treatment. We thank HOCO, Holstebro WWTP, Nibsbjerg 424 waterworks and MEC for providing data. We would like to thank Anders Damgaard from DTU 425 Environment for his assistance with EASETECH and Palle Lindgaard-Jørgensen from DHI for 426 giving insight to the dairy production and providing eco-efficiency guidance. S.L. Larsen and M. 427 Rygaard received funding from the Danish Environmental Protection Agency through the project 428 Water Efficient Dairies.

\section{ABBREVIATIONS}

430 LCA, life-cycle assessment; LCC, Life-cycle costing; VA, value added; VCA, value chain 431 analysis; WWTP, wastewater treatment plant; MBR, Membrane bioreactor; RO, reverse osmosis;

432 FU, functional unit; MEC, Maabjerg energy center; COD, chemical oxygen demand; T-N, total 433 nitrogen; T-P, total phosphorus; ILCD, International Reference Life Cycle Data; FWI, freshwater 434 withdrawal impact; TVA, total value added: EEI, eco-efficiency indicator 


\section{REFERENCES}

Agerbo, K. 2016. Personal communication.

Azapagic, a. and S. Perdan. 2000. Indicators of sustainable development for industry: a general framework. Trans IChemE 78(July): 243-261.

Bankrate. 2016. Current Mortgage Interest Rates. https://www.bankrate.com. Accessed April 11, 2016.

Bhupendra, P. 2016. Personal communication.

Bidwell, R. and H. Verfaillie. 2000. A Guide to Reporting Company Performance.

Boulay, A.M., J. Bare, L. Benini, M. Berger, M.J. Lathuillière, A. Manzardo, M. Margni, et al. 2018. The WULCA consensus characterization model for water scarcity footprints: assessing impacts of water consumption based on available water remaining (AWARE). International Journal of Life Cycle Assessment 23(2): 368-378.

Clavreul, Julie and Guyonnet, D. and Christensen, T.H. 2012. Quantifying uncertainty in LCAmodelling of waste management systems. Waste Management 32(12): 2482-2495.

Clavreul, J., H. Baumeister, T.H. Christensen, and A. Damgaard. 2014. An environmental assessment system for environmental technologies. Environmental Modelling \& Software 60: $18-30$.

Clift, R. 2009. Industrial Ecology and its application to Sustainable Production and Consumption. In . Centre for Environmental Strategy.

Compton, M., S. Willis, B. Rezaie, and K. Humes. 2018. Food processing industry energy and 
water consumption in the Pacific northwest. Innovative Food Science \& Emerging Technologies 47: 371-383.

Dalsgaard, T. 2016. Personal communication.

Deowan, S.A., S.I. Bouhadjar, and J. Hoinkis. 2015. Membrane bioreactors for water treatment. In Advances in Membrane Technologies for Water Treatment, 155-184. Elsevier. https://linkinghub.elsevier.com/retrieve/pii/B9781782421214000058. Accessed August 31, 2019.

Doorn, M.R.J., S. Towprayoon, S.M. Manso Vieira, W. Irving, C. Palmer, R. Pipatti, and C. Wang. 2006. Wastewater Treatment and Discharge. In 2006 IPCC Guidelines for National Greenhouse Gas Inventories, 6.1-6.28.

Faragò, M., S. Brudler, B. Godskesen, and M. Rygaard. 2019. An eco-efficiency evaluation of community-scale rainwater and stormwater harvesting in Aarhus, Denmark. Journal of Cleaner Production 219: 601-612.

Frischknecht, R., N. Jungbluth, H.-J. Althaus, G. Doka, R. Dones, T. Heck, S. Hellweg, et al. 2005. The ecoinvent Database: Overview and Methodological Framework. The International Journal of Life Cycle Assessment 10(1): 3-9.

Godskesen, B., M. Hauschild, H.-J. Albrechtsen, and M. Rygaard. 2018. ASTA — A method for multi-criteria evaluation of water supply technologies to Assess the most SusTainable Alternative for Copenhagen. Science of the Total Environment 618.

Godskesen, B., M. Hauschild, M. Rygaard, K. Zambrano, and H.J. Albrechtsen. 2013. Life-cycle 
and freshwater withdrawal impact assessment of water supply technologies. Water Research 47(7): 2363-2374.

Harder, R., G.M. Peters, N.J. Ashbolt, and M. Svanström. 2017. Using quantitative microbial risk assessment and life cycle assessment to assess management options in urban water and sanitation infrastructures: Opportunities and unresolved issues. Microbial Risk Analysis 5: 71-77. https://doi.org/10.1016/J.MRAN.2016.11.004.

Hauschild, M.Z. 2015. Better - But is it Good Enough? On the Need to Consider Both Ecoefficiency and Eco-effectiveness to Gauge Industrial Sustainability. In The 22nd CIRP Conference on Life Cycle Engineering, 1-7. Elsevier B.V.

Heijungs, R., E. Settanni, and J. Guinée. 2013. Toward a computational structure for life cycle sustainability analysis: Unifying LCA and LCC. International Journal of Life Cycle Assessment 18(9): 1722-1733.

Henze, M., W. Gujer, T. Mino, T. Matsuo, M.C. Wentzel, G.V.R. Marais, and M.C.M. Van Loosdrecht. 1999. Activated Sludge Model No.2D, ASM2D. Water Science and Technology 39(1): 165-182.

Holstebro municipality. 2008. Strukturplan $1 \quad-\quad$ Renseanlæg. https://www.vestforsyning.dk/media/1457/strukturplan_spildevand.pdf. Accessed February $2,2016$.

Hunkeler, D.J., K. Lichtenvort, G. Rebitzer, and A. Ciroth. 2008. Environmental life cycle costing. Vol. 1. SETAC / CRC Press. 
Huppes, G. and M. Ishikawa. 2007. Quantified Eco-Efficiency - An Introduction with Applications. 22nd ed. Springer.

Hybel, A.-M., B. Godskesen, and M. Rygaard. 2015. Selection of spatial scale for assessing impacts of groundwater-based water supply on freshwater resources. Journal of Environmental Management 160: 90-7.

ISO. 2012. Environmental management - Eco-efficiency assessment of product systems Principles, requirements and guidelines (ISO 14045:2012).

JRC - European commission. 2011. ILCD Handbook: Recommendations for Life Cycle Impact Assessment in the European context. European Union.

Kleinfeld, I.H. 1993. Engineering economics: Analysis for Evaluation of Alternatives. New York, USA: Van Nostrand Reinhold.

Laso, J., I. García-Herrero, M. Margallo, I. Vázquez-Rowe, P. Fullana, A. Bala, C. Gazulla, Á. Irabien, and R. Aldaco. 2018. Finding an economic and environmental balance in value chains based on circular economy thinking: An eco-efficiency methodology applied to the fish canning industry. Resources, Conservation and Recycling 133: 428-437.

Laurent, A., M.Z. Hauschild, L. Golsteijn, M. Simas, J. Fontes, and R. Wood. 2013. Deliverable 5.2: Normalization factors for environmental, economic and socio-economic indicators.

Lorenzo-Toja, Y., I. Vázquez-Rowe, M.J. Amores, M. Termes-Rifé, D. Marín-Navarro, M.T. Moreira, and G. Feijoo. 2016. Benchmarking wastewater treatment plants under an ecoefficiency perspective. Science of The Total Environment 566-567: 468-479. 
https://linkinghub.elsevier.com/retrieve/pii/S0048969716310403. Accessed August 31, 2019.

Macfadyen, G., A.M. Nasr-Alla, D. Al-kenawy, M. Fathi, H. Hebicha, A.M. Diab, S.M. Hussein, R.M. Abou-Zeid, and G. El-Naggar. 2012. Value-chain analysis - An assessment methodology to estimate Egyptian aquaculture sector performance 弥. Aquaculture 362-363: $18-27$.

Martinez-Sanchez, V., M.A. Kromann, and T.F. Astrup. 2015. Life cycle costing of waste management systems: overview, calculation principles and case studies. Waste Management 36: $343-55$.

Meneses, Y.E., J. Stratton, and R.A. Flores. 2017. Water reconditioning and reuse in the food processing industry: Current situation and challenges. Trends in Food Science \& Technology 61: $72-79$.

Miljø- og Fødevareministeriet. 2015. Bekendtgørelse om vandkvalitet og tilsyn med vandforsyningsanlæg. Denmark.

Miljø- og Fødevareministeriet. 2016a. Bekendtgørelse om spildevandstilladelser m.v. efter miljøbeskyttelseslovens kapitel 3 og 4 . Denmark.

Miljø- og Fødevareministeriet. 2016b. Bekendtgørelse om jordbrugets anvendelse af gødning i planperioden 2015-2016.

Miljøministeriet. 2011. Vandplan 2010-2015. Nissum Fjord. Hovedvandopland 1.4 Vanddistrikt: Jylland og Fyn. 
Moreau, V. and B.P. Weidema. 2015. The computational structure of environmental life cycle costing. The International Journal of Life Cycle Assessment 20(10): 1359-1363.

Naturstyrelsen. 2013. Det vandløse mejeri. Miljøministeriet.

Nielsen, L. 2016. Personal communication. Holstebro.

Pearce, D., G. Atkinson, and S. Mourato. 2006. Cost-benefit analysis and the environment: Recent developments. OECD Publishing.

PlanteavlsKonsulenten. Værktøjer - DB - regneark.

Rad, S.J. and M.J. Lewis. 2014. Water utilisation, energy utilisation and waste water management in the dairy industry: A review. International Journal of Dairy Technology 67(1): 1-20.

Rivera, X.C.S. and A. Azapagic. 2016. Life cycle costs and environmental impacts of production and consumption of ready and home-made meals. Journal of Cleaner Production 112: 214228.

Saling, P., A. Kicherer, B. Dittrich-Krämer, R. Wittlinger, W. Zombik, I. Schmidt, W. Schrott, and S. Schmidt. 2002. Eco-efficiency analysis by BASF: the method. The International Journal of Life Cycle Assessment 7(4): 203-218.

SEGES. 2015. Gødskning efter n-min-metoden 2015.

Sikdar, S.K., P. Glavič, and J. Ravi. 2004. Technological choices for sustainability. 1st ed. Springer-Verlag Berlin Heidelberg.

Søndergaard, G.L., P.J. Binning, M. Bondgaard, and P.L. Bjerg. 2018. Multi-criteria assessment 
tool for sustainability appraisal of remediation alternatives for a contaminated site. Journal of Soils and Sediments 18(11): 3334-3348. http://link.springer.com/10.1007/s11368-017$1805-2$.

Stakhiv, E. and B. Stewart. 2010. Needs for Climate Information in Support of Decision-Making in the Water Sector. Procedia Environmental Sciences 1(1): 102-119.

Technical University of Denmark. 2016. EASETECH. Www.Easetech.Dk. www.easetech.dk.

Vestforsyningen A/S. 2015. Priser.

Weidema, B.P. and M.S. Wesnaes. 1996. Data quality management for life cycle inventories-an example of using data quality indicators. Journal of Cleaner Production 4(3-4): 167-174. 